\title{
Unsettled Narratives: Graphic Novel and Comics Studies in the Twenty-First Century - A Preface
}

\begin{abstract}
Comic art and graphic narrative constitute a varied and multifaceted chapter in the cultural history of the contemporary age. When comics gained a foothold on the mass-media scene, they appeared as an object that was new, and indefinable. As is often the case when facing a novelty, there was a reactionary response. In fact, the slippery nature of the emerging medium resulted in widespread rejection by the establishment and a variety of negative connotations. Labelled for much of the twentieth century as a genre intended for children, or as second-rate cultural products, or even as morally harmful, in recent times, comics have begun to be re-evaluated by academics, particularly in the West. Even though today there remains a tendency to emphasize the literary value of individual works rather than their nature as sequential art, many negative connotations of the past have given way to an increasing need to understand how the comics medium works and what makes graphic narration so peculiar.
\end{abstract}

Keywords: academic re-evaluation, comics studies, cultural bias, cultural studies, graphic narrative, graphic novel, history of comics, semiotics, Umberto Eco, unsettled medium

\section{The fate of comics}

The fate of comics is a varied and multifaceted chapter in the cultural history of the contemporary age. Labelled for much of the twentieth century as a genre intended for children, as second-rate cultural products, or as a morally harmful narrative form, it is only in very recent times that comics have begun to be re-evaluated by academics, particularly in the West. In fact, with cultural effects that are still easily appreciable today, these narrative forms have become increasingly interesting to academics even as they have expanded to include more, and more serious, concerns. Importantly, this history of discredit cannot be generalized globally; in this respect, scholarship and culture in the West have lagged behind those of other communities. The key example is in Japan, where the reputation and diffusion of comics among different age-groups allowed the medium practically to replace traditional literature. Thus, a global account of the place of comics 
and other graphic narratives must balance this more advanced and established appreciation of the comic art against the stigma applied to English-language products and other main comics traditions, such as the Franco-Belgian, Italian, or Argentinian ones.

The ever-widening place of comics in academic communities globally has relied on specific traditions and, significantly, an expansion of the form in the US specifically. While illustrated stories for children - arguably a form of graphic narrative - were appreciated earlier at least for their educational value in many nations, comics narratives (of the type associated with the sequential art of the bande desinée) obtained substantial international attention from critics and academics only following the publication of the two volumes of Art Spiegelman's Maus in 1986 and 1991, collecting the chapters that appeared as inserts in the magazine Raw beginning in 1980. The debate generated by this comics memoir encouraged the multiplication of essays on comics titles, a phenomenon that would be boosted about a decade later by the English-language edition in two volumes of another comics memoir, Persepolis by Marjane Satrapi. These personally and politically powerful narratives took up themes and experiences of international significance in a style that was at once verisimilitudinous and comics-like: the works looked graphically like comics for young readers, but handled important and emotionally devastating conduct with genuine maturity.

Considering that many other noteworthy comics works had been produced before these two graphic novels, the reasons for such notable interest may lie in a fortunate combination of factors. On the one hand, it could be argued that an older highbrow debate opposing literary fiction and genre fiction reverberated in the field of drawn narrative, and that the appearance of two significant works with a literary profile was therefore successfully able to awaken interest in comics and allow connoisseurs, scholars, and critics to finally make it appear legitimate. Maus was a moving historical biography on the experience of the author's father as a survivor of the Shoah - what in many countries is called the Holocaust while Persepolis was a fascinating historical autobiography, narrating the author's growth during and after the Islamic Revolution in Iran. These events were not only of local or personal importance: the narrated and illustrated experiences inform global views of ethics, morality, and equality. On the other hand, the particular historical moment should be taken into account in each case. Maus was released during the last phases of the collapse of the Soviet Bloc and the fall of the Berlin Wall; Persepolis appeared at the turn of the new millennium, at a crucial moment in the dialogue (or confrontation) between the West and the Islamic world, which included a revived debate on the condition of women in a changing world. In addition to that, the style of both Maus and Persepolis is not realistic in itself, but rather mimics the aesthetics of comics for children, such as talking, humanized 
animals (typical of Disney comics), which confers nonetheless a powerful poetical value on the two works and, to borrow from Scott McCloud, enhances readers' identification with the protagonists. Thus, the artists were able to skilfully use the characteristics of the comics medium in order to present controversial information in a less threatening way.

In effect, these works opened up possibilities for further artists and writers to treat material of personal, political, and international importance. The truthfulness of these particular stories is also critical as a watershed event. Social, historico-cultural, and geopolitical factors had conspired to keep masterpieces such as El Eternauta or $V$ for Vendetta in a sort of shadow; they were capable of conveying crucial cultural critiques, but without the traction that victimization by Nazis or conservative religious reform conferred on Maus or Persepolis. And El Eternauta and $V$ for Vendetta are just two previous works that criticized the contemporary political situation but were unable to set the step-change in motion. Hence, it is not unreasonable to say that it was necessary to wait until the time was ripe and the right works were published for comics to achieve a wider and stronger scholarly reputation.

That Maus and Persepolis were a watershed in the academic history of comics and graphic novels stems not only from their ability to draw additional graphic narratives into academic discourse, but also from the fact that an existing intellectual tradition was available to undertake the necessary theoretical work. Whilst the millennium change brought an international burgeoning of scholarly publications dedicated to comics studies, continental studies on graphic narrative, comics, and the comics medium go back to the sixties; their roots can be found in the field of semiotics and cultural studies. In 1963, at a time when comics were generally disregarded by Italian academia as second-rate popular literature meant for children and immature (or almost illiterate) adults, Umberto Eco wrote in his preface to the volume Arriva Charlie Brown! [Here Comes Charlie Brown!]:

\footnotetext{
It is not true that comic strips are a harmless amusement, which, though created for children, can also appeal to adults, seated in their easy-chairs after dinner, a bit of escapism to be enjoyed without harm and without gain. The mass culture industry produces comics on an international scale and distributes them on every level [...]. The comic strip is commissioned from above, it operates according to all the mechanisms of hidden persuasion, it presupposes in the consumer an attitude of escape that immediately stimulates the paternalistic aspirations of the producers. And, as a rule, authors conform: thus the comic strip, in most cases, reflects the implicit pedagogy of a system and acts as hidden reinforcement of the dominant myths and values. (Eco 1994, 37-38)
}

Eco added that there are also comic strips with an insightful satirical value, such as Jules Feiffer's works, and deeply poetic comic strips such as George Harriman's Krazy Kat or Peanuts, whose poetry originates from a lyrical repetition of the 
same theme in different comic-strip variants day after day. A revised version of the preface would be included the following year in Eco's Apocalittici e integrati [Apocalyptic and Integrated], where the author also performed a sociological-cultural study of the myth of Superman and a semiotically relevant analysis of Milton Caniff's Steve Canyon. Eco's essays gave great impetus to comics studies in Europe and worldwide, not only of a semiotic or a socio-cultural nature, but also from various other scholarly perspectives, such as the pedagogical, the psycho-cognitive, and the literary.

Comics studies today still confronts many of the same cultural problems and questions the medium had to face originally. When comics gained a foothold on the mass-media scene, they appeared as an object that was new as well as indefinable. As is often the case when facing a novelty, there was a reactionary response: comics were something new, but also slippery and indefinable. The result was widespread rejection by the establishment and a variety of negative connotations. Even though today there remains a tendency to emphasize the literary value of individual works rather than their nature as sequential art, many negative connotations of the past have given way to an increasing need to understand how the comics medium works and what makes graphic narration so peculiar.

\section{The contributions}

The wish to highlight the very unsettled nature of narration in a highly unsettled medium brought the ICLA Research Committee on Comics Studies and Graphic Narrative to choose, for its first ICLA panel as a formally constituted group, a title that displayed the distinctive character of our subject of research in the evolving landscape of narrative media. Organized within the framework of the 2016 ICLA conference in Vienna, the panel "Unsettled Narratives: Graphic Novel and Comics Studies in the 21st Century" hosted presentations that addressed the questions raised by comics and graphic narratives from various perspectives, following the tradition of the research team since the 2004 ICLA conference in Hong Kong. The papers published here reflect work on US comics from a non-US perspective (Buchenberger and Paladin) and on comics in various national traditions (Ursini, Rossi, Ask Nunes); work that considers the transformation and reception of comics either in national traditions (Grüning, Piepoli) or as adaptations of the Gothic (Halsall); and more theoretical considerations (DeTora, Piepoli). We hope that readers enjoy the collection of papers, which has arisen from the hard work of our contributors as well as of colleagues from within the comics studies and graphic narrative research community who kindly served as advisors and peer-re- 
viewers, especially Kai Mikkonen, David Coughlan, Adnan Mahmutovic, Takayuki Yokota-Murakami, and Riccardo Capoferro.

\section{Work cited}

Eco, Umberto. “The World of Charlie Brown.” 1963. Trans. William Weaver. Apocalypse Postponed. By Eco. Ed. Robert Lumley. Bloomington and Indianapolis: Indiana University Press, 1994. 36-44.

Dr Angelo Piepoli received his $\mathrm{PhD}$ in Information and Communication Theory from the University of Macerata in 2007. He is a scholar of semiotic textology and the history and techniques of comics. He acted as a research collaborator at the former Department of Social Change, Legal Institutions, and Communication, and as a teaching assistant for courses in semiotics and applied semiotics at the former Faculty of Communication, at the University of Macerata, where he collaborated with the linguist and semiotician János Sándor Petőfi. He has published various contributions on comics studies in journals such as Heteroglossia and IJOCA, as well as in volumes such as Il '68 Diffuso, Prospettive di Semiotica del Testo, and Imaginaire et Idéologie du Plurilinguisme Littéraire et Numérique. He acted as editor-in-chief, programme director, and writer at Radio Università di Macerata, where he presented Splash Page!, a radio programme on comic art and publishing. He is a founding member of the ICLA Research Committee on Comics Studies and Graphic Narrative.

Dr Lisa DeTora's interest in graphic narrative research began with an edited volume, Heroes of Film, Comics, and American Culture (2009). Her education includes a PhD and MA in English (University of Rochester), graduate certificate in Women's Studies (University of Rochester), and an MS in Clinical Bioethics (Albany Medical College). As an assistant professor at Hofstra University, Dr DeTora teaches for curricula in writing studies and rhetoric, medical humanities, narrative medicine, and advanced scientific writing at undergraduate and graduate levels. Dr DeTora publishes in various journals on medical rhetoric, technical communication, comparative literature, and biomedicine. Her recent activity in graphic narrative research includes organizing seminars about embodiment and visual narratives of medicine at the American Comparative Literature Association congresses (2015 to 2018). 
Dr Umberto Rossi is an independent scholar, teacher, and literary critic with wide-ranging intellectual interests - notably war literature, science fiction, Philip K. Dick, Thomas Pynchon, and J. G. Ballard - who has published and presented numerous papers in Italian and English. He has recently edited a collection of essays on Thomas Pynchon's V. (with Paolo Simonetti), Dream Tonight of Peacocks' Tails (2015). A consistent contributor to the Research Committee on Comics Studies and Graphic Narrative at the ICLA, Dr Rossi has also organized numerous seminars and panels. In 2017, he co-organized a series of panels, "Between Fear and Safety: Post-Memory in 'European' Comics and Graphic Narratives,” with Kai Mikkonen for the European Network of Comparative Literary Studies conference held in Helsinki. These panels included scholars from across the world. The conceptualization of these panels drew on Rossi's interests in war literature and graphic narrative. 